\title{
Features of teaching a translator special vocabulary in the modern linguistic and economic situation
}

\author{
Galina Ostrikova and Olesya Kolesnikova* \\ Don State Technical University, 344002, Rostov-on-Don, Russia
}

\begin{abstract}
This article studies the problem of teaching translators in special vocabulary in the modern linguistic and economic situation. In our time, science is constantly developing. The rapid development of science and technology has revealed the need for training translators to pay close attention to the ability of future translators to work with terms and special vocabulary found in various fields of activity. The article also raises the question of what knowledge students should have before teaching them special vocabulary, that is, the predecessors of such special seminars should be such language disciplines as linguistics, lexicology of the German language, phonetics of the German language, etc. The research was carried out on the material of special dictionaries and scientific and technical texts, in which a large number of German and Russian term units were found. Consideration of terminological systems of subject areas of informatics and cybernetics seems to be especially relevant, since this group of terms is one of the most important parts of a complex terminology system in modern science. As a result of the study, the elements of the terminology system were combined into some thematic groups. Further, the ratio of terms and professionalisms, the shadows of their meaning, origin and use were considered.
\end{abstract}

\section{Introduction}

An in-depth study of individual problems of lexicology is the basis for the development of such professional skills of future linguists and translators as the ability to work with theoretical and reference literature, the ability to pose and solve feasible scientific problems, as well as the ability to present the studied material in the form of written or oral speech.

It seems important to conduct a study of theoretical issues in connection with visual practical material. So, the problems of terminology are most naturally considered due to the study of special vocabulary. Teaching special vocabulary in senior courses can take place in the form of special seminars, which are a combination of classroom studies and students' independent work.

Special vocabulary, as the most developing part of the vocabulary of the language, allows you to study theoretical problems and solve practical problems of terminology.

\footnotetext{
*Corresponding author: Ole-ole-olesija@yandex.ru
} 
To increase the clarity of training and increase the share of independent work of the student when organizing work with special vocabulary, it is necessary to use multimedia technologies and visual aids. [1-2]

Teaching special vocabulary of modern terminological systems, for example, computer science, management or marketing, representing the latest branches of knowledge, contributes to both the assimilation of theoretical material and the intensification of independent scientific work on the problem under the study. Recent studies in the field of organizing certain aspects of independent work confirm the effectiveness of its use in the formation of communicative competence in the learning of foreign languages, including at the professional level [3].

\section{Materials and Methods}

The composition of the special vocabulary itself is rather heterogeneous. Most researchers distinguish several layers in the special vocabulary: nomenclature terms and collective names (T. L. Kandelaki, G. I. Akhmanova); terms, nomenclature and proper names (G. V. Stepanov, V. M. Leichik); terms, nomenclature names, professionalisms (T. S. Kogotkova, T. R. Kiyak); terms, nomens, dialectisms, historicisms (A.V. Superenskaya); normative terminology, non-normative terminology and nomens (G. M. Shipitsyna, Z. I. Komarova); terms, professionalism, professional vernacular (N. P. Kuzmin); where terminology includes nomenclature marks.

This article researches the special vocabulary of modern terminology systems using the example of the terminology system of informatics and cybernetics, taking into account the scope and peculiarities of the use of their units, as well as the processes of interaction of special vocabulary with common vocabulary. The subject of our research is a group of elements of the term system of the subject areas of computer science and cybernetics, the component of the meaning of which goes back to the commonly used nominal lexical units. This group is an important part of the complex terminology of these sublanguages. The quantity of studied units is $1-2 \%$ of the total volume of terms. The totality of these units, which have common patterns of education, is an essential component of the system.

Special dictionaries and scientific and technical texts (more than 8500 pages) were the material of the study. In the course of the study, 206 German and 192 Russian terminology units were analyzed, which were identified by means of a continuous sample from specialized lexicographic sources and scientific texts. The study also used descriptive and synchronous-comparative methods.

In connection with the development of science and technology, a lot of new phenomena, concepts, devices and apparatuses appear, for which stylistically neutral terms are not always sufficient, therefore it becomes necessary to designate these phenomena, concepts, devices, etc. The commonly used word attracts specialists with its imagery and emotional coloring. As the living practice of term formation shows, specialists and inventors of terms often prefer emotionally colored ones to neutral units [4]. Most of the studied elements of the terminology system are formed by metaphorical rethinking. Metaphorization has recently been considered one of the topical types of semantic terminology [5].

\section{Literature Review}

The situation of "terminological explosion", which scientists have always written about and are still writing about, gives rise to the need for new terms. According to experts, about 1000 new scientific and technical words appear annually, and in Russian, English, French and Czech the number of terms is from 50 to $80 \%$ of new words and meanings [6]. There 
are problems associated with the transformation of terminology into a controlled process: streamlining, unification, standardization, internationalization. Therefore, of interest, first of all, are the universal regularities of the replenishment of terminological systems.

The designation "terminology" was introduced into scientific circulation in 1959, although the study of special vocabulary, individual terminology systems and their units began much earlier. Currently, terminology is considered a science, which has its object of terminology and terms, a science that differs in subject, methods, approaches and material from linguistics, although it uses linguistic methods to study the linguistic aspects of terms. The idea that the science developing the theories of the process of ordering terminology, an independent scientific discipline, was further developed abroad, in the works of E. Wuester, P. Agron, in the materials of numerous international conferences and symposia, embodied in the activities of terminology organizations. And for domestic science it is an honor that this idea was first heard from the pages of its publications.

The object of the study of linguistics is language in its entirety. Terminology deals exclusively with terms, and not with all scientific and technical vocabulary. Even nomenclature names are acceptable by the terminology of only relative terms. Terminologists are engaged in the development of systems of terms in a particular area, in terminology they are primarily interested in the content plan, the identification of links between scientific and technical concepts. Consciousness of scientific terminological systems is not only a matter of terminologists, but also of philosophers, logicians, specialists, and linguists.

V. V. Vinogradov figuratively called the history of terminology "a story about the laws governing the development of knowledge about nature and society." The origin of the national school of terminology can be considered the 20 s - early 30 s of the XX century. Its founders are called academician S. A. Chaplygin, scientist D. S. Lotte and linguist professor G. O. Distiller. Aspects of working with special vocabulary are diverse and include both theoretical (ordering by terminology, the boundaries of the term, its normativity), lexicographic and applied issues, and methodological (methods of compiling dictionaries, principles of filing terms in dictionaries, methods of ordering terminology) tasks, as well as concerning the fixation of the prevailing use of special vocabulary, control over the observance of uniform designations of concepts and some others [7].

Terminology has long been considered as a significant part of the language, extending to it the general laws of the language. In turn, terminology serves as a constant source of enrichment of the vocabulary of the language. The works of such researchers as V. P. Danilenko, T. L. Kandelaki, V. M. Leichik, L. L. Kutina, L. A. Kapanadze, V. N. Prokhorov and others. Linguistic criteria and features of terms are comprehensively described, problems such as sources of formation of terminological systems, variance in terminology, the relationship between terminology and vocabulary of other layers of the language, as well as problems of analyzing individual terminological systems, speech culture and many others are discussed.

Terminology, according to the definition of a dictionary, is a system of a certain field of science, production or art. Terminology or terminological vocabulary is also called the entire set of terms of any language. Being, according to A. A. Reformatsky, "a servant of two masters", a system of vocabulary and a system of scientific concepts, terminology acquires special problems in this regard. One of these problems is the relationship between a concept, a term and a word. There are different opinions on this issue. Some researchers associate the term with a concept, others emphasize the nominative tendency of the term, its subject correlation.

Most often, the features of a term are revealed in the opposition "term is not a term". It should be noted that there is no clear answer to the question of what is the essence of a term as a special lexical unit. Researchers distinguish different special functions of the term - 
nominative (G.O. Vinokur), significative (V.A.Zvegintsev, A.G. Aksyonov), identifiable and distinctive (K. Gausenblas), definitive (V.V. Vinogradov).

At the moment, there seems to be no disagreement in the understanding of the term as a word or phrase associated with the concept of any area of activity or knowledge. The term, being a member of the general lexical system, differs from other everyday words in a number of features that meet certain requirements. The founder of the Russian terminological school D.S. Lotte noted: "Any scientific and technical term, as opposed to an ordinary word (or phrase), should have a limited, firmly fixed content. This content should belong to the term regardless of the context, while the meaning of an ordinary word is specified only in a certain context with other words" [8].

Among the listed D. S. Lotte criteria for the term - systemic conditioning, its independence from the context, absolute and relative unambiguity, accuracy and brevity, which are accepted by many linguists. The question of the stylistic characteristics of the term remains controversial. Some scholars insist on its stylistic neutrality as a relevant feature (A. A. Reformatsky, G. O. Vinokur, R. A. Budagov, L. A. Kapanadze, etc.), others adhere to the opposite point of view, namely the term not always devoid of emotionally expressive components of meaning (R. G. Piotrovsky, V. N. Prokhorova, V. V. Petrov, etc.).

Recently, researchers have noted that there is growing interest in the term both as a means of scientific cognition and as a means of verbalizing a scientific concept. Sorokina E. A. believes: "The transformation of a word into a term is a historical process associated with the progressive development of thinking and dependent on it. The appearance of a term is the result of scientific understanding and verbalization of one of the concepts as an element of the conceptual field" [9].

It is well known that from G. O. Vinokur, the delineation of terminology and nomenclature in theoretical terms is carried out and found its continuation in the works of A. A. Reformatsky. At present, some provisions of the works of famous linguists are being questioned. Many researchers disagree on whether nomenclature should be included in the area of terminology, given the fact that there is no clear boundary between terminology and nomenclature. Despite this, the nomenclature is usually considered as a separate layer closely related to terminology, which together with it constitutes a special vocabulary. In the works of A. V. Superenskaya, T. L. Kandelaki, V. M. Leichik is given a detailed study of nomenclature in terms of content and expression.

In general, can be said that nomenclature is a more artificial part of special vocabulary compared to terminology. Its units, nomens, often denote specific objects and objects, constructions, methods and methods, phenomena, some quantities, etc., therefore the nominative function prevails in them. If a term, as a rule, has a definition, then a description is more characteristic of a nomen, conveying its individual characteristics. Optional features of nomenclature designations can be considered relative independence from the context, objectivity and materiality.

The solution to the question of the relationship between the term and professionalism is also ambiguous. A clear definition of professionalism and the name of this layer of special vocabulary are given in the work of L. I. Barannikova [10]. The author distinguishes between two types of special vocabulary - unofficial, everyday, often falling out of the system of the literary language, and official, codified. Moreover, the center of the official vocabulary is terminology, and the central part of the unofficial vocabulary is the reduced deterministic vocabulary, which is used for unofficial everyday communication. It is noted that the words having replaced the official terms and nominations in the context of informal communication are called professionalisms. Their main differences from the terms are manifested in changes in the plan of expression towards simplification and reduction of the structure and the possibility of the appearance of additional connotative coloration. It is 
appropriate to recall here that at present there is an ever-increasing process of convergence of special vocabulary with common vocabulary, which occurs in the form of interaction. The general aspects of this interaction are being studied and constantly supplemented by researchers [11-14].

All of the above problems of special vocabulary are necessary objects of study for students who have chosen the profession of a translator, since mastering this profession involves not only the free use of the language in its general literary form, but also the ability to communicate in various professional spheres of communication.

\section{Results and discussion}

Of particular interest in terms of transforming a lexical unit into a term is the layer of elements of the terminology system of informatics and cybernetics with a subject-shaped component of meaning, which go back to common words. The studied material came into contact more often with concepts related to technology, functioning and description of specific devices and their parts. The "subject matter" of the objects of research, apparently, predetermines the search for sources of term units in the system of everyday concepts. The group under study is the result of the formation of elements of terminological systems from ready-made lexical units. In this case, it is probably more legitimate to talk about the "recoding" of a lexical unit, since there is a process of its transition from one code to another. Now, according to a number of researchers, the semantic method of term formation has changed the nature of its implementation [15].

As a result of the analysis of the material under study and its correlation with the initial semantics, it was established that the elements of the term system can be combined into conditional thematic groups. Since the connection of special vocabulary with common vocabulary is considered, the basis for the unification of the studied units into certain groups was their initial general linguistic semantics. Here we agree with the authors who refer to the common vocabulary of the words of the main vocabulary fund, which denote objects and phenomena encountered in everyday life [16]. This also includes the units united by the theme "Man". See table 1 .

Table 1. Examples of units of informatics and cybernetics special vocabulary, formed on the basis of common words with the topic "Man"

\begin{tabular}{|c|c|c|c|}
\hline № & German term unit & Russian term unit & $\begin{array}{c}\text { Terminological concept or } \\
\text { interpretation of a term unit }\end{array}$ \\
\hline 1 & Vater & otets (father) & $\begin{array}{c}\text { The name of the vertex (tree) in } \\
\text { relation to other vertices. }\end{array}$ \\
\hline 2 & Eltern & roditel(i) (parents) & $\begin{array}{c}\text { The name of the vertex (s) in the } \\
\text { tree in relation to other vertices. }\end{array}$ \\
\hline 3 & Tochter & doch (daughter) & $\begin{array}{c}\text { The name of a vertex (node) in a } \\
\text { tree (graph) in relation to another } \\
\text { (parent) vertex (node). }\end{array}$ \\
\hline 5 & Sohn & syn (son) & $\begin{array}{c}\text { The name of a vertex (node) in the } \\
\text { system of trees (graphs) in relation } \\
\text { to the parent vertex (node) }\end{array}$ \\
\hline 6 & Bruder & brat (brother) & $\begin{array}{c}\text { A tree node that has the same parent } \\
\text { node as this node. }\end{array}$ \\
bratia (brothers) & Kind(er) & $\begin{array}{c}\text { potomok(i) } \\
\text { (descendant) }\end{array}$ & $\begin{array}{c}\text { The vertex (s) of one parent in the } \\
\text { tree Or: the vertex to which the arc } \\
\text { from the given vertex leads. }\end{array}$ \\
\hline
\end{tabular}




\begin{tabular}{|c|c|c|c|}
\hline 7 & Enkel & potomok (descendant) & $\begin{array}{c}\text { Same: Kind. Or: the top of the tree } \\
\text { below the given top. }\end{array}$ \\
\hline 8 & Großvater & predok (ancestor) & $\begin{array}{c}\text { The top of the tree located above } \\
\text { the given top. }\end{array}$ \\
\hline 9 & Nachbar & sosed (neighbor) & $\begin{array}{c}\text { 1. An element in an ordered set. } \\
\text { 2. The top of the tree in relation to } \\
\text { another (neighboring) top of the } \\
\text { tree. }\end{array}$ \\
\hline 10 & Urgroßvater & predok (ancestor) & Same: Großvater \\
\hline 11 & Zwillings-(-punkt) & $\begin{array}{c}\text { a) type of algorithm; } \\
\text { b) metod bliznetsov } \\
\text { (twins method) }\end{array}$ & $\begin{array}{c}\text { b) a method of dynamic memory } \\
\text { allocation, in which blocks of size } \\
\text { equal to a power of 2 are allocated; } \\
\text { adjacent free blocks of equal length } \\
\text { merge. }\end{array}$ \\
\hline 12 & Familie & semeystvo (family) & $\begin{array}{c}\text { 1. A set of objects that have } \\
\text { common features. } \\
\text { 2. A set of products and tools that } \\
\text { are partially compatible with each } \\
\text { other: computers, operating } \\
\text { systems, programming languages. }\end{array}$ \\
\hline
\end{tabular}

In the material of the research in the Russian and German languages, five groups of terminological units with the original semantics were distinguished: "Artifacts", "Man", "Nature", "Many objects" and a group that unites heterogeneous elements that did not receive a common thematic name.

The group "Artifacts" includes subgroups of designations:

a) household items - Kamm / greben (comb), Nadel / igla (needle), Schlüssel / klyuch (key), etc.;

b) garments, fabrics and threads - Schleife / petlya (loop), Band / lenta (ribbon), Fahne / flag (flag), etc.;

c) structures and their parts - Brücke / most (bridge), Fenster /okno (window), Konsole / konsol (console), etc.;

d) institutions and means of communication - Post / poshta (post), Brief / pismo (letter), Adresse / adres (adresse), etc.

In Russian, this group includes a subgroup of names of stationery and educational supplies such as "book", "pencil", "folder", etc.

The group "Man" includes the following subgroups, denoting:

a) family relations - Vater / otets (father), Sohn / syn (son), Kind /potomok (child), etc.;

b) professions and occupations - Bibliothekar /bibliotekar (librarian), Arbiter / arbitr (arbiter), etc.;

c) social characteristics of a person - Nachbar / sosed (neighbor), Nachfolger / posledovatel (successor), etc.;

d) human qualities - Narr / durak (fool), etc.;

e) body part names - Kopf / golova (head), Rumpf /telo (trunk), Skelett / skelet (skeleton), etc.

The "Nature" group is represented by the names of living beings, parts of their bodies, products and housing, as well as the names of flora, geographical and topographic names Maus / mysh (mouse), Wald / les (forest), Feld / pole (field), Monte-Carlo / Monte-Karlo (Monte-Carlo), etc.

The fourth group contains the designations for "multiple objects" such as Warteschlange / ochered (queue), Halde / kucha (heap), Büschel / puchok (tufts), etc. 
The last group united the units that were not included in the previous ones - Alphabet / alfavit (alphabet), Menü / menyu (тепu), Loch /dyrka (hole), etc.

The fifth group unites term units that are not included in the listed thematic Alphabet / alfavit (alphabet), Labyrinth /labirint (labyrinth), Rendezvous /randevu (rendezvous), Menü / menyu (menu), Atom / atom (atom), etc.

The term unit at the beginning of its functioning in this area still retains its primary denotative reference and the familiar environment characteristic of its general linguistic use. The proof of this is the context and specific distribution of the studied elements of the term system. By context, it is meant the use of a term unit in one or several sentences, and by distribution, and the immediate environment of the term, its valence and use in phrases. The examples below show the elements of the term system retaining their original distribution and having a context characteristic to one degree or another for common vocabulary. Certain patterns can be traced in these examples. Firstly, these units are characterized by joint use, that is, within the framework of one sentence, several term units of the same plan can be found. Secondly, a certain term unit affects the choice of the class of the surrounding vocabulary, namely the selection of: a) verbs; b) adjectives and c) other nouns of the same semantic group. For clarity and the possibility of comparison, examples of the use of elements of the terminology system in Russian and German are given together at the beginning of the description of a separate group. Various thematic groups were considered, but the most expressive in terms of their preservation of the original distribution and "imagery" were the elements of the terminology system, correlated with the semantic basis "Man" (in particular, the terms of kinship), "Flora", "Mail". Apparently, units united in some microsystems are the preferred source of terminology. Where the system is more organized, the terminology process is faster, as, for example, in the subgroup of kinship terms, in which a clear hierarchical system is embedded in everyday terminology itself. Elements of this term system, dating back to the terms of kinship, have become widespread in the field of data representation - graph theory.

Let us give examples of the use of elements of the term system, correlated with the semantics of "kinship terms" in

a) Russian:

- The root of the tree contains the name of the set, and each node of the tree has a pointer to its otets (father) in the tree.

- In a rooted oriented tree, the vertex $w$ is a potomok (descendant) of the vertex $v$ (and $v$ is the predok (ancestor) of the vertex $w$ ) if there is a path from $v$ to $w$. The vertex $w$ is the syn (son) of the vertex $v$ (and $v$ is otets (the father) of the vertex $w$ ) if $(v, w)$ is an edge in the given tree.

- Two nodes that have one otets (father) are called bratia (brothers). We also define the degree of a tree node as the number of its sons.

- Each node has no more than two "detey"("children"), located so that the subnode on the left has a key less than the key of the "roditelya"("parent"), and the subnode on the right has a larger key.

- In an ordered tree, we can talk about the first, second and last synoviakh (sons) of a particular node. The first syn (son) of a node is often referred to as the eldest syn (son) of the node, and the last son is often referred to as the youngest.

b) German:

- Söhne desselben Vaters nennt man Brüder. So sind z.B. H, I und J Brüder. Diese Terminologie kann man im Bedarfsfall erweitern, z.B. können wir nach dem Großvater von M fragen, der D ist usw.

- Zu einem Vater werden die Kinder der gesuchten Datengruppen bestimmt.

- Jeder Sohn gibt an den Vater die beste vom Sohn zum Ziel führende Route und deren Kosten zurück. 
- Das Eintreffen der Telegramme weckt die entsprechenden Söhne.

- Der Vater «kreiert» Söhne, indem er Nachrichten in den Briefkasten der Sohnprozessoren ablegt.

- In Anlehnung an Stammbäume spricht man anstatt von Vorgänger und Nachfolger auch von Vater und Sohn.

Examples of the use of elements of the terminology system, correlated with the semantics of "Mail" in

a) Russian:

- Elektronaya pochta (Email) has many advantages. For example, the sender and the addressee may not be in place at the same time, but the text will be transmitted.

- Every morning the editor of the publishing house Franzis sits down in front of the screen and looks at how many pisem (letters) have accumulated in pochtovom yashchike (an email inbox) in the last 24 hours.

- The following sections of the article describe the functionality and some techniques for implementing the corresponding system, which we will call pochtoy (mail). Poghta (Mail) is based on pochtovykh yashchikov (the mailbox) method.

b) German:

- Es gibt die Möglichkeit der Benutzerkommunikation durch elektronische Post.

- Jeder Benutzer hat einen privaten und vor unerlaubtem Zugriff geschützten

\section{Briefkasten.}

- Ist der Brief angekommen?

- Der Benutzer braucht sich nicht um die Übertragungswege, auch nicht um die Sicherung seiner «Botschaft» zu kümmern.

The peculiarity of the studied terminology system of informatics and cybernetics is that these and similar elements retain at a certain stage keeping the connection with the corresponding thematic groups. This is confirmed by the choice of the surrounding vocabulary, as well as the construction of phrases such as podrezka derevyev (tree pruning), rasshcheplenie kornya dereva (tree root splitting), potomki odnogo roditelya (descendants of one parent), synovya odnogo ottsa - bratia (sons of one father are brothers), etc.

The analysis of our material testifies to the predominant metaphorization of certain thematic groups. It is important for us that in the course of our research the universal tendencies in the development of metaphors have been confirmed. S. Ullman, for example, believed that the associations underlying figurative rethinking are deeply rooted in human experience and largely independent of culture and environment [17].

Changing the meaning of an everyday word through metaphorization is not contraindicated in special terminology systems. In the process of terminology of common units by means of metaphorical rethinking, the same mechanism of metaphorization continues to operate, which is inherent in the language as a whole.

Moreover, a large number of the total number of identified term units (44\% of Russians and $40 \%$ of German) have the original semantic theme "Artifacts". That is, where the signified and signifiers are the most familiar and "objective" in the material sense of the word, the process of transformation of an ordinary word into a special one takes place more easily and more often.

\section{Conclusions}

The investigated elements of the term system represent a special group of term units that retain in their meaning the subject-shaped component at the initial stage of functioning. The proof is that the term units have a distribution familiar to the general language lexical unit.

Even in a technical text, the term unit is not completely free from previous connections. 
The identification in the terminology of computer science and cybernetics of a certain layer of elements formed by changing the meaning of everyday words with a subjectshaped component is of great importance in the study of the problems of special vocabulary in general, as well as issues of translation of such vocabulary in particular, which is important for the development of professional skills of future linguists and translators. The study of the peculiarities and new trends in the development of special vocabulary in new areas of knowledge, such as the indicated informatics, as well as marketing, logistics and others, in the modern linguistic and economic situation is the key to the future successful activities of translators in their multifaceted profession.

Researchers have repeatedly noted that the terminological vocabulary of the specialty is one of the means of forming professionally oriented communicative competence, that is, the ability to direct foreign language communication in the implementation of professional activities [18]. Therefore, teaching special terminological vocabulary is a necessary and essential condition for the full-fledged formation of professionally oriented communicative competence of students.

\section{References}

1. S. V. Kalashnikova, The world of science, culture, education 3 (70), 40 - 42 (2018).

2. G. N. Ostrikova, M. R. Zheltukhina, I. A. Zyubina, I. G. Sidorova. Astra Salvensis VI, 601-607 (2018).

3. M. R. Zheltukhina, L. L. Selenskaya, G. N. Ostrikova, E. A. Redkozubova, O.O. Chernova, XLinguae 14 (1), 249-269 (2021). DOI: 10.18355 / XL.2021.14.01.19

4. Max Black, Studies in language and philosophy (1962).

5. M. N. Kozhina, Scientific and technical revolution and the functioning of the languages of the world (1977).

6. V. A. Sobyanin, Interaction of special and everyday vocabulary in modern German (2005).

7. T. L. Kandelaki, Questions of Linguistics 5, 123 - 132 (1979).

8. D. S. Lotte, Foundations of construction of scientific and technical terminology (1961).

9. E. A. Sorokin, Cognitive aspects of lexical design (to the basics of cognitive terminology) (2007).

10. L. I. Barannikova, S. A. Massina, Language and Society 9, 3 - 15 (1993).

11. O. Yu. Shmeleva, Bulletin of ChelSU 17 (198), 149 - 155 (2010).

12. I. R. Yunusova, Bulletin of the Bashkir University 14 (3), 857 - 860 (2009).

13. K. Rincke, Alltagssprache, Fachsprache und ihre besondere Bedeutungen für das Lernen. Zeitschrift für Didaktik der Naturwissenschaften 16, 235-260 (2010).

14. J. Segers, Das Phänomen der terminologischen Variation als Herausforderung für Übersetzer Ein Beitrag zur IATE-Datenbank der EU 13 (2016).

15. A. V. Kryzhanovskaya, L. A. Simonenko, Topical Problems of Ordering Scientific Terminology (1987).

16. Aina Blinken, Development of scientific and technical terminology (1973).

17. S. Ulman, Semantic universals. New in linguistics (Issue U, Moscow, 1970).

18. A. A. Myasnikov, The role of terminological vocabulary in the formation of the communicative competence of non-philological students (2009). 